\title{
Therapeutic Strategies for Leukodystrophic Disorders Resulting from Perinatal Asphyxia: Focus on Myelinating Oligodendrocytes
}

\author{
Justyna Janowska ${ }^{1} \cdot$ Joanna Sypecka $^{1}$ (D) \\ Received: 18 January 2017 / Accepted: 7 June 2017 / Published online: 28 June 2017 \\ (C) The Author(s) 2017. This article is an open access publication
}

\begin{abstract}
Perinatal asphyxia results from the action of different risk factors like complications during pregnancy, preterm delivery, or long and difficult labor. Nowadays, it is still the leading cause of neonatal brain injury known as hypoxicischemic encephalopathy (HIE) and resulting neurological disorders. A temporal limitation of oxygen, glucose, and trophic factors supply results in alteration of neural cell differentiation and functioning and/or leads to their death. Among the affected cells are oligodendrocytes, responsible for myelinating the central nervous system (CNS) and formation of white matter. Therefore, one of the major consequences of the experienced HIE is leukodystrophic diseases resulting from oligodendrocyte deficiency or malfunctioning. The therapeutic strategies applied after perinatal asphyxia are aimed at reducing brain damage and promoting the endogenous neuroreparative mechanisms. In this review, we focus on the biology of oligodendrocytes and discuss present clinical treatments in the context of their efficiency in preserving white matter structure and preventing cognitive and behavioral deficits after perinatal asphyxia.
\end{abstract}

Keywords Perinatal asphyxia $\cdot$ Neonatal hypoxia-ischemia Oligodendrocyte progenitors $\cdot$ Myelinogenesis $\cdot$ Myelin structure $\cdot$ Electron microscopy $\cdot$ Neuroprotection $\cdot$ Cell-based therapies

Joanna Sypecka

jsypecka@imdik.pan.pl

1 NeuroRepair Department, Mossakowski Medical Research Centre, Polish Academy of Sciences, 5 Pawinskiego str., 02-106 Warsaw, Poland

\section{Introduction}

Perinatal asphyxia is the leading cause of neonatal brain injury known as hypoxic-ischemic encephalopathy (HIE). Accordingly, it is evoked by a temporarily limited (sometimes over a considerably prolonged period of time) supply of oxygen, which in turn leads to hypoxia or even anoxia in severe cases. The transiently reduced cerebral blood flow (ischemia) also results in the shortage of trophic support, especially the distribution of glucose. Perinatal asphyxia concerns about 4-6 of every 1000 full-term births and it is even more frequent in the case of children born prematurely [1]. Preterm delivery, which accounts for as much as $10 \%$ of newborns, as well as complications during labor are the major causes of birth asphyxia and make it to be the one of the leading causes of under-five child deaths [2-4]. Thanks to a constant progress in neonatal care programs, the mortality rate among newborn children has a tendency to decrease [5-7]. Nonetheless, the experienced deficiencies of oxygen and trophic support very often affect various body organs, including brain and trigger long-time consequences influencing the quality of life. Those include neurodevelopmental (neuromotor disorders, seizures, limb paresis) as well as cognitive and behavioral impairments [8-11].

Unfortunately, the cells constituting the neonatal nervous tissue are extremely sensitive to alterations in local homeostasis. In the perinatal period, a huge amount of neural progenitors arises in the effect of intense processes of neurogenesis and gliogenesis, contributing to the development of the central nervous system (CNS). The newly born neuroblasts give rise to specialized neurons like motoneurons, sensory neurons, or interneurons, which are responsible for behavioral and cognitive functions, as well as the interaction between those cells, respectively [12-14]. The physiological functioning of neurons is based on fast and efficient processing and transmitting 
signals within nervous system; therefore, any alterations usually lead to neurological disorders, which are pronounced to different extend. The process of signal transduction is highly energy-consuming and therefore neurons are supported by glial cells, which are present in at least an equal proportion to neurons, depending on a given brain region [15-17]. To enable salutatory conduction which is an efficient way of speeding-up propagation of impulses, axons are wrapped with myelin, elaborated by oligodendrocytes, the specialized glial cells.

\section{Alterations in Oligodendrocyte Development}

Myelin, which insulates axons and facilitates signal conduction, is essentially a compact multilamellar and highly organized structure $[18,19]$. Generally, it is an extended and modified plasma membrane of oligodendrocytes, which are the cells responsible for myelinating CNS. Their precursors arise from neuroectoderma and populate the developing nervous system starting from approximately mid-gestation [20-22]. Gliogenesis is known to peak at the perinatal period and it proceeds intensely during the first postnatal months, in the course of constant neurogenesis. However, to gain capability for myelinogenesis, oligodendrocytes undergo a multistep process of maturation, which could be described by the expression of overlapping cell-specific markers (Fig. 1). Accordingly, the glial commitment of the neural stem cells is associated with the presence on their surface, the A2B5 marker (Fig. 1a), corresponding to ganglioside GT3 and its $O$-acetylated derivative epitope [23]. Oligodendrocyte progenitors cells (OPCs) (Fig. 1c-d) are commonly distinguished by the expression of transmembrane chondroitin sulfate proteoglycans (also known as NG2: neuron-glial antigen 2), which has been shown to be engaged in the cell migration and response to pathological signals [24-26]. The oligodendrogliabiased progenitors could be also distinguished by the expression of lineage-specific transcription factors $\mathrm{Nkx} 2.2$ and Olig2 [27-29]. Different localization of Olig1/Olig2 (either nuclear or cytosolic) is associated with the regulation of myelin genes and - after phosphorylation and acetylation - in process outgrowth $[30,31]$. Interestingly, a significant number of NG2positive cells, sometimes with already well-elaborated cell processes and therefore identified as polydendrocytes (Fig. 1e) [32, 33], remains in their undifferentiated state and is scattered in the brain parenchyma, both in the white and the gray matter [34]. They demonstrate a high proliferative potential and were shown to be the major population of cycling cells within the CNS [35-37].

OPCs however are the ultimate precursors of myelinating cells. The progress is their differentiation is associated with the appearance on the cell surface, the $\mathrm{O} 4$ and $\mathrm{O} 1$ markers (Fig. 1f-h), which are sulfatides attributed to immature cells,
Fig. 1 Differentiation of rat oligodendrocytes in a primary culture. Cell nuclei are stained with Hoechst 33258 (blue). a Neural stem cells, clearly discernible due to the expression of $\mathrm{A}_{2} \mathrm{~B}_{5}$ marker (red), which are already oligodendroglia-biased (Olig-1 marker, green). b Oligodendroglial progenitors characterized by either nuclear (arrows) or cytosolic presence of transcription factor Olig-2 (green) after $24 \mathrm{~h}$ of in vitro culture. c Dividing OPCs expressing NG2 (red) and Ki67 (green) markers, indicating proliferating cells. d Visualization of PDGF-AA receptor (PDGF $\alpha \mathrm{R}$, green) characteristic for OPCs. e Immature NG2positive cells (green), which are characterized by branched cell processes (polydendrocytes). f Immature oligodendrocytes recognized by their typical marker $\mathrm{O} 4$ (red), which are still able to divide, as indicated by Ki67 staining (green). g After $48 \mathrm{~h}$ of in vitro culturing, differentiating $\mathrm{O}^{+}$(red) oligodendrocytes express the $\mathrm{GalC}$ antigen (green). $\mathbf{h}$ The next step of oligodendrocyte $\left(\mathrm{GalC}^{+}\right.$, red $)$differentiation associated with the expression of myelin components $\left(\mathrm{MBP}^{+}\right.$, green). $\mathbf{i}$ Maturating cells recognized by their two most characteristic markers: $\mathrm{CNP}$ (red) and GalC (green). $\mathbf{j}$ Vanishing $\mathrm{O} 4$ presence (red) is replaced by GalC (green) expression in multibranched cells with long cellular extensions. $\mathbf{k}$ Cells with complex morphology, characterized by the presence of $\mathrm{GalC}$ (red) and MBP (green). I Mature oligodendroroglia expressing major myelin proteins: PLP (red) and MBP (green). m Magnification of double-labeled differentiated (PLP-red, MBP-green) myelinating oligodendrocyte on day 5 of in vitro culture

often termed pre-oligodendrocytes [38-41]. More advanced stages of oligodendrocyte maturation could also be identified by the intracellular presence of 2', $3^{\prime}$-cyclic nucleotide-3'-phosphodiesterase of CNPase (Fig. 1i), an enzyme engaged in myelin synthesis and maintenance [42, 43]. Differentiated cells are stained with a common marker against galactosylceramidase (GalC) (Fig. 1i-k), an enzyme hydrolyzing certain galactolipids, which are integrative myelin molecules [44-46]. Initiating myelin component synthesis opens up a new opportunity for immunostaining the mature oligodendrocytes. The antibodies against myelin basic protein (MBP), proteolipid protein (PLP) (Fig. 1k-m), myelinassociated glycoprotein (MAG), and myelin oligodendrocyte glycoprotein (MOG) are commonly used to visualize both the cells and the formed myelin sheaths [47-52]. Gained ability for myelinogenesis is the endpoint of oligodendrocyte maturation.

However, differentiation of progenitors into oligodendrocytes with extended and branched cell processes is an energyconsuming process. It requires constant trophic support to sustain the maturation process; otherwise, it could be inefficient or even arrested. As mentioned above, capability for myelinogenesis is associated with the activation of the set of genes coding for specific protein and lipid components and elaboration of several layers of lipid-rich layers of tightly compacted membrane. Poor vasculature or temporal limitation of oxygen and metabolic substrates due to reduced blood pressure might result in transient hypoxia, subsequently leading to activating the Wnt signaling pathway by upregulating the expression of hypoxia-inducible factors (HIFs) in oligodendrocytes [53]. Accordingly, in physiological oxygen level (also termed as "physioxia" and corresponding to $2-5 \%$ in 


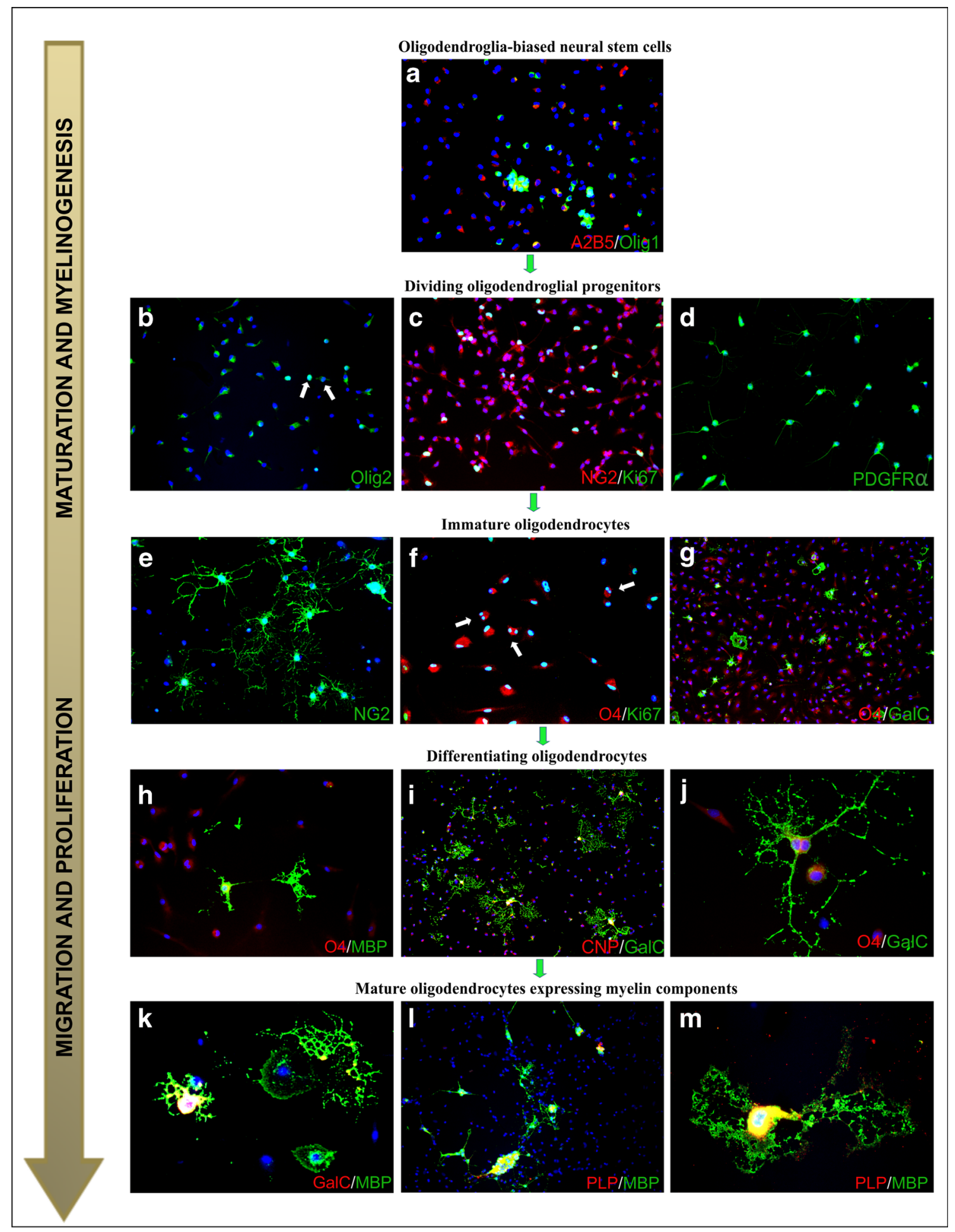

nervous tissue), perinatal OPC-expressed HIF arrests cell differentiation yet promoting angiogenesis through Wnt7 signaling pathway in a paracrine manner. Once the microvasculature is established, HIF $1 \alpha$ and HIF $2 \alpha$ are deactivated by specific oxygen-dependent enzymes (asparaginyl and prolyl hydroxylases) and oligodendrocyte differentiation proceeds.
There is a growing list of evidence that oligodendrocytes are extremely sensitive to the alteration in local homoestasis and they respond to various kinds of pathological signals by either limited survival and arrested maturation process [54-57] or by increasing their proliferation rate and migrating towards the site of injury $[37,58,59]$. 


\section{Myelination of CNS by Mature Oligodendrocytes}

Competed oligodendrocyte maturation means acquiring an ability to express myelin components, their intracellular transport, and incorporation into forming myelin sheaths. Although myelin is an extension of oligodendroglial cell membrane, its composition is highly modified in context of protein to lipid proportion. Whereas in cell membrane, this ratio is approximately $1: 1$, in myelin lipids constitute up to $70-85 \%$ lipids of dry mass, comprising predominantly cholesterol, galactosylceramide, and ethanolamine plasmalogen, which enable the close packing and tight organization of molecules within the membrane $[60,61]$. Thus, numerous genes have to be activated (some of them are regulated by HIFs and therefore depend on the local level of oxygen) to express specific myelin components. The processes of membrane modification and generation have to be orchestrated and very efficient since large myelin quantities are elaborated by a given oligodendrocyte. In the CNS, almost all axons with diameters greater than $0.2 \mu \mathrm{m}$ are myelinated and a large myelinated axon may have up to 250 to 300 turns of myelin wrapping around it [62]. Accordingly, the ratio between axon diameter and that of the total nerve fiber (axon and myelin) has been established to be about $0.6-0.7$. Moreover, one oligodendroglial cell is responsible for myelinating several axons (making even 40 myelin segments) and is able to produce as much as $5-50 \times 10^{3} \mu^{2}$ of membrane a day [63]. Once established, myelin sheath is maintained by oligodendrocytes throughout adulthood, contributing to accelerating signal transduction even about 50-100-fold (up to $70-120 \mathrm{~m} / \mathrm{s}$ for axons with diameter about 2-20 $\mu \mathrm{m}$ ) [62].

Myelinated axons, besides being able to efficiently and rapidly propagate signals, are also protected by myelin from exogenous noxious stimuli. Neurodegenerative disorders developing in a consequence of CNS hypo/demyelination are actually based on unmyelinated axon dystrophy and their malfunctioning. A lesson learned from animal models point to the wide spectrum of neurological symptoms resulting from insufficient CNS myelination. They are pronounced to different extend, strongly depending on the severity of CNS dys/ demyelination and include among others body tremor, focal sensory loss, limb paresis, and ataxia. Taking into consideration that during evolution, the amount of white matter tremendously increased achieving in primates and humans about $60 \%$ of brain volume (versus about 10\% in rodents) [15], precise and efficient myelination seems to be crucial for correct CNS functioning.

\section{Leukodystrophic Disorders Resulting from Perinatal Asphyxia}

Delayed and/or disturbed maturation of oligodendrocytes, triggered by temporal limitation of oxygen and trophic support due to perinatal hypoxic-ischemic event, results in CNS hypomyelination and contributes to development of leukodystrophic diseases (Fig. 2). Since pathological insults affect various brain regions to a different extent, also the functions of oligodendrocytes would be either retained or altered and white matter lesions are diffused. The local intensity of inflammatory processes and the density of an extant vasculature have a significant impact on oligodendrocyte maturation and their efficiency in properly assembling myelin layers. It has been reported that endothelial cells associated with vessels play an important role in promoting the proliferation and survival of oligodendrocytes by secreting trophic stimuli to local microenvironment, defined as "oligovascular niche" [64-66]. Moreover, the enhanced vascularization process observed after stroke promotes oligodendrocyte survival and maturationareas of the highest vessel density were also characterized by greater number of differentiated oligodendrocytes - suggesting a crucial role of constant trophic supply in physiological maturation of oligodendrocytes $[67,68]$. Trophic coupling between endothelium and oligodendrocytes had been shown to contribute to maintaining the brain-blood barrier integrity [69]. Altogether, angiogenesis supporting cell survival, proliferation, and paracrine activity seems to be part of a strategic response to pathological clues leading to white matter injury.

In our in vivo studies on impact of perinatal asphyxia on oligodendrocyte survival and maturation in rat model, pathological changes in nervous tissue of various brain regions (hippocampus, striatum, corpus callosum, cerebral cortex) were observed even several weeks post insult. Accordingly, the ultrastructural examination by means of electron microscopy revealed many symptoms of locally ongoing inflammatory process like neuropil edema, collapsed small blood vessels, and macrophage infiltration (Fig. 3). However, the angiogenesis in the traumatized tissue was also detected, usually as the bridging vessels. The areas significantly depleted from mature oligodendrocytes were notified as well, which might correspond to the development of the diffuse white matter injury (DWMI) - one of the most characteristic outcomes of the HI episode [57, 70, 71].

Apart from limitation of trophic support and development of inflammatory process, the oxidative stress is thought to play a pivotal role in oligodendrocyte survival and differentiation after the hypoxic-ischemic insult. Increase in the level of free radicals (molecules containing an unpaired electron in an atomic orbital), especially the reactive oxygen species (ROS) and the reactive nitrogen species (RNS), strongly affects cell functioning and leads to the imbalance in local homeostasis. While at the physiological levels, ROS and RNS, generated during adenosine triphosphate (ATP) production by mitochondria, contribute to regulation of the cell survival and proliferation; their excess exerts a negative impact, especially by directly impairing mitochondrial function and often leading to an apoptotic cell death [72, 73].

In this way, oxidative stress is particularly harmful to oligodendrocytes due to their high metabolic demands and 
Fig. 2 Impact of temporal hypoxia on the biology of oligodendrocytes. The processes of oligodendroglial differentiation, maturation and the capability for myelinogenesis are highly energy-consuming and are supported by metabolites provided by circulating, oxygenated blood (upper panel). Perinatal asphyxia leads to a decrease in blood pressure and a temporal limitation in oxygen and glucose supply (lower panel). Maturation of oligodendrocytes is arrested and myelinogenesis is altered/delayed

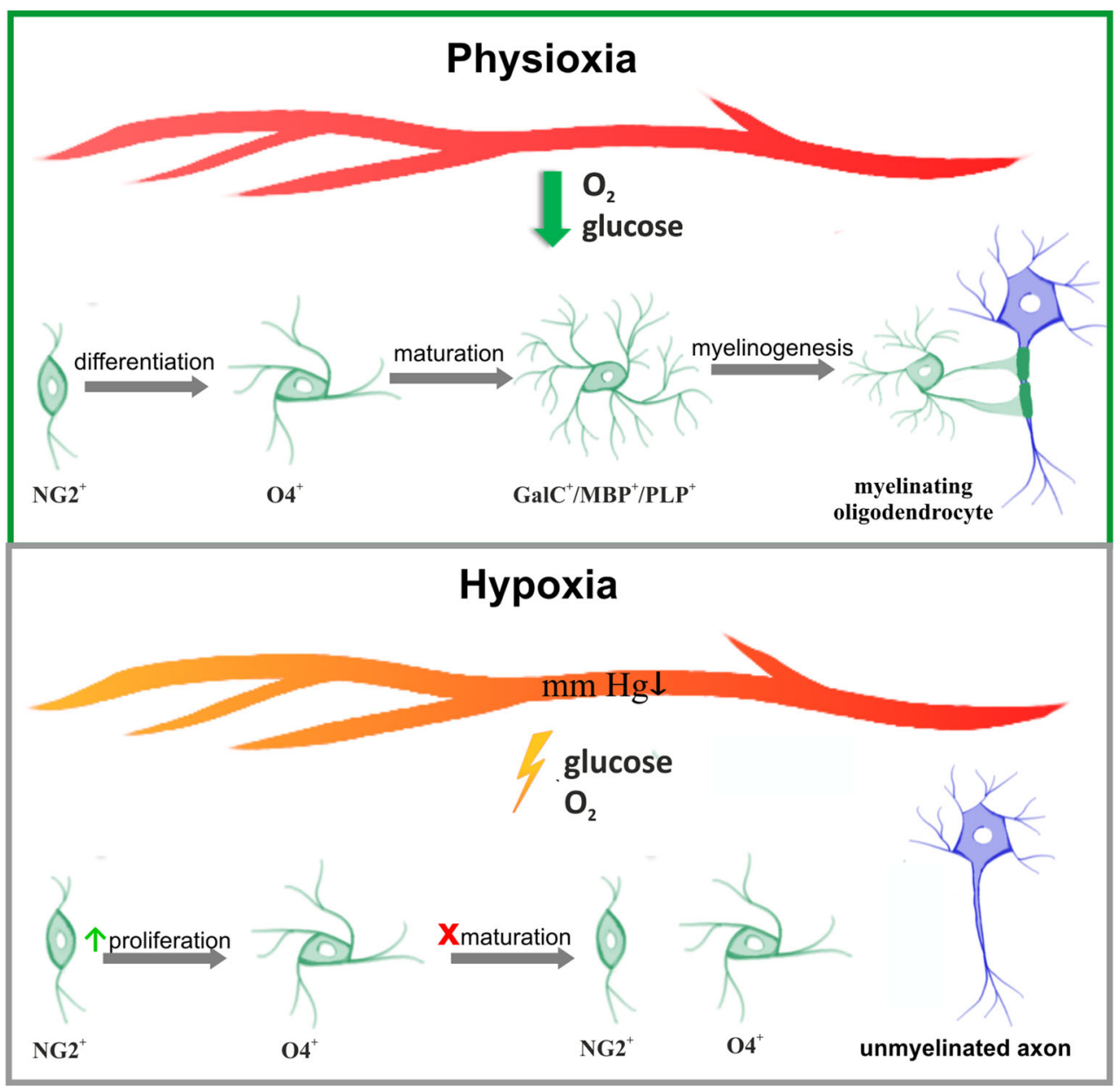

mitochondrial activity associated with generation and maintenance of myelin membranes. Since the process is energy dependent, significant amounts of ATP and oxygen are utilized, contributing to the increase in the ROS and RNS levels due to intense metabolism. Additionally, the high iron content, characteristic for oligodendrocytes and necessary for myelinogenesis, might contribute to generation of free radicals and subsequent lipid peroxidation. Free radical formation is also enhanced by cytokines associated with inflammatory process, which in reciprocal manner might enhance the ongoing inflammation, since hydrogen peroxide and ROS are used by the immune system as cytotoxic mediators [74]. It has been shown that pro-inflammatory cytokine-mediated downregulation of myelin genes is redox sensitive [75]. Free radicals might also participate in disrupting oligodendrocyte maturation by upregulating the expression of differentiation-inhibiting genes (like ID2, ID4) and downregulating the expression of genes promoting oligodendrocyte maturation (Sox10, Olig1, Olig2), by epigenetic mechanisms involving histone acetylation (repression of gene coding histone deacetylase 3, HDAC3) [76].

Physiologically, the detrimental effects of free radicals are prevented by several enzymes of antioxidant defense comprising superoxide dismutase-1 and dismutase-2 (SOD), catalase
(CAT), glutathione peroxidase (GPx), and glutathione-Stransferase (GST). Oligodendrocytes, especially in the developing brain, are however characterized by the low concentrations of glutathione and SODs which would prevent either oxidative or nitrosative injury $[77,78]$. Thus, supplementation with antioxidants which act as free radical scavengers seems to be indispensable for sustaining oligodendrogial functions after perinatal asphyxia.

Development of oxidative stress as a consequence of the experienced incident of perinatal asphyxia and its potential severity might be evaluated by determination of different biochemical markers, which usually are the products of reactions triggered by the excess of free radicals. While some of them are useful as indicators of lipid peroxidation (which also indirectly might provide information about myelin damage, like the presence of F2-dihomo-isoprostanes) [79], others correspond to either DNA or protein oxidative damage [80]. Reliable parameters, measured in the biologic fluids (plasma, urine, spinal fluid) and tissues, include relative concentration of isoprostanes (F2-IsoPs, F3-IsoPs), neuroprostanes (F4NeuroPs), nonprotein-bound iron (NPBI), protein adducts of 4-hydroxynonenal (4-HNE PAs), and advanced oxidation protein products (AOPP), as well as the calculated ratio of 

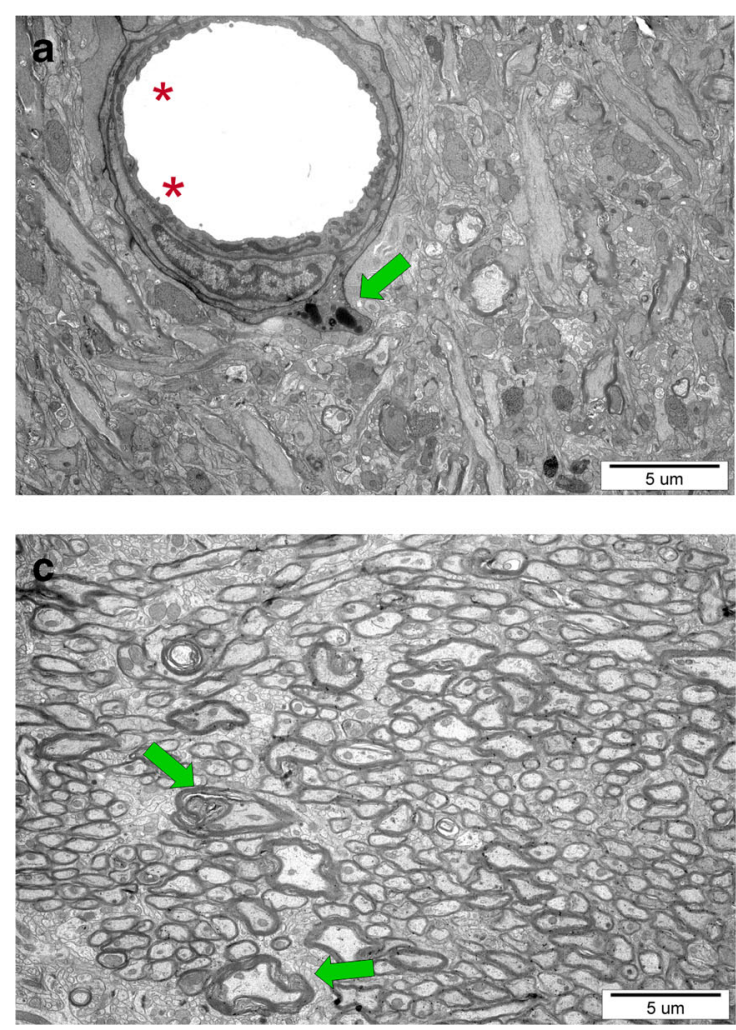

Fig. 3 Ultrastructure of nervous tissue obtained from control and experimental rat brains 7 weeks after perinatal asphyxia performed in 7day-old rat. a Corpus callosum of H-I rat: characteristic microvilli on the endothelium surface (red asterisk) and a macrophage cell residing in the blood vessel wall (green arrow) suggesting temporal interruption of blood-brain barrier. b Activated microglial cells (green arrow) with

reduced glutathione (GSH) to oxidized glutathione (GSSG), which might be considered as either predictive or discriminative indicator of oxidative stress [81-84].

Regional lack or malformation of myelin sheaths corresponding to CNS dys/demyelination unfortunately is not the only one outcome of deficiency of the mature oligodendrocytes. Beyond their major role of ensheathing axons of large and medium caliber [85], oligodendrocytes also were shown to support the nervous cells with energetic substrates like glycogen-derived pyruvate/lactate via the monocarboxylate transporter 1 [86-88] and with trophic factors [89]. The latter include factors promoting neurogenesis and protecting neurons after a temporal imbalance in tissue homeostasis. Thus, deficiency of either mature oligodendrocytes or even their undifferentiated progenitors could negatively influence survival of stressed neurons or those newly born after the insult.

\section{Rescuing Infants from Neonatal Hypoxic-Ischemic Event}

To prevent neurodevelopmental impairments, which are being anticipated as fatal consequences of perinatal asphyxia,
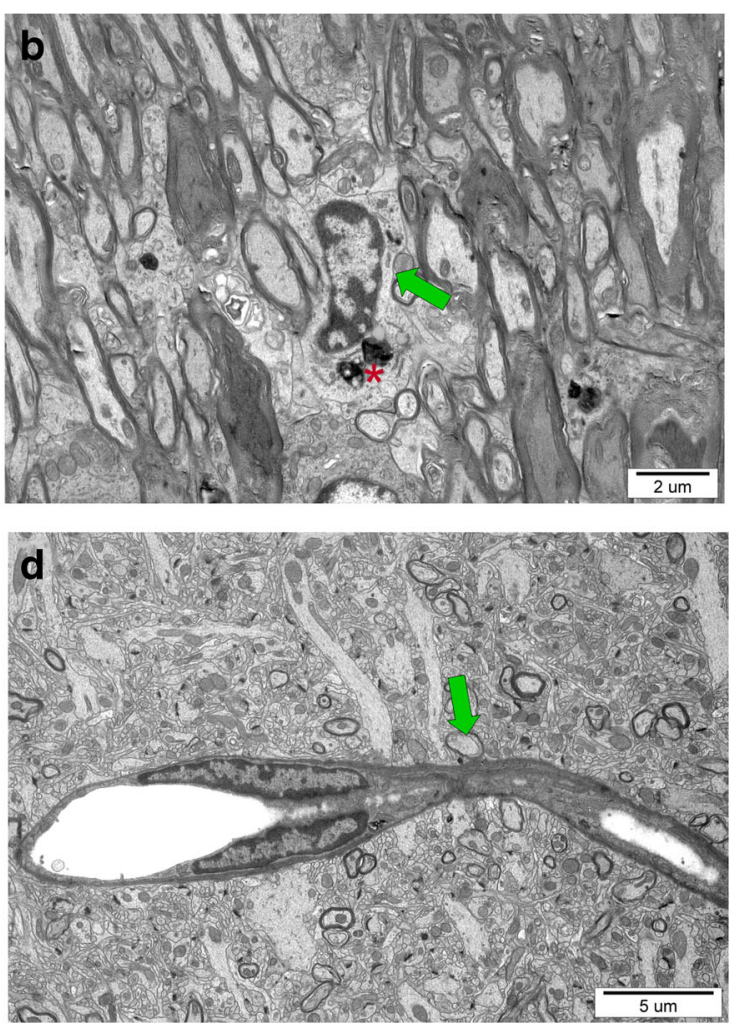

numerous lysosomes (asterisk), filled with hydrolytic enzymes, in the hippocampus of H-I rats. c Malformed myelin sheaths with splitting lamellae in striatum of injured rats. $\mathbf{d}$ The bridging vessel (green arrow) in $\mathrm{H}-\mathrm{I}$ rats indicating the ongoing angiogenesis, conducive to processes of neurorestoration

different types of remedies have been designed and recommended for clinical implementation (Fig. 4). In clinical practice, the very first treatment applied to the baby who has experienced neonatal hypoxia-ischemia and is unable to breathe without assistance is mechanical ventilation to restore the physiological level of blood oxygenation. To attain this goal, it is also necessary to stabilize blood pressure and to avoid hyperoxygenation which could have severe detrimental effects like bronchopulmonary dysplasia (BPD) and retinopathy of prematurity [90,91]. Accordingly, the ventilatory support of term infants should be carried out with air and in the case of preterm infants, either air or a low concentration of oxygen (about 30\%) should be applied, avoiding large-volume inflations $[92,93]$. At the time of or after resuscitation, the body temperature should be maintained between 36.5 and $37.5{ }^{\circ} \mathrm{C}$ to ensure infant survival; however, later on mild hypothermia - either selective (head) or systemic (body) - is considered effective therapy preventing the development of neurological dysfunctions. Hypothermia as treatment is recommended for rescuing infants with moderate to severe HIE and is usually based on maintaining body temperature at 33$33.5^{\circ} \mathrm{C}$ for $72 \mathrm{~h}$ followed by slow and controlled rewarming [94-97]. The published meta-analysis study revealed that mild 


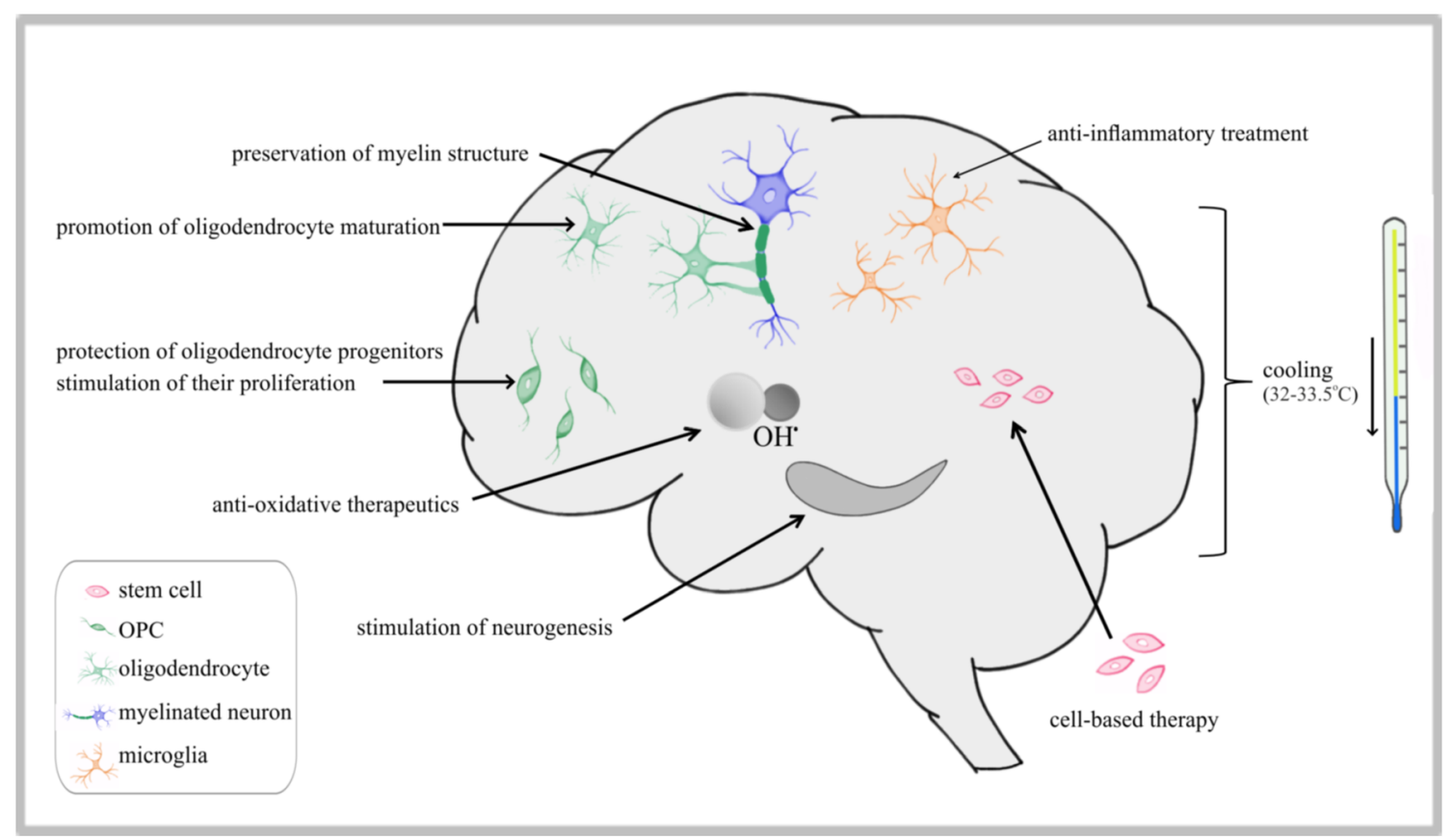

Fig. 4 The scheme of targets for therapeutic intervention after perinatal asphyxia. The first and most effective is head cooling applied immediately after the injury, aimed at avoiding/limiting injures resulting from temporal hypoxia-ischemia. Current strategies are based on preventing the development of leukodystrophic disorders (antioxidative, neuroprotective are myelin-preserving protocols) and favoring endogenous neuroreparative mechanisms (providing antiinflammatory therapeutics and trophic support)

\section{Pharmacological Treatments to Prevent Developmental Disabilities}

For the last two decades, a number of natural biological substances has been included in preclinical studies on animal models, as well as used as treatments in a clinical practice (Table 1). The first group consists of the analogues of physiological compounds, which are known to play important roles in various biological processes. One of them is melatonin $(N-$ acetyl-5-methoxy tryptamine), tested in the context of its utility in preventing neurodevelopmental disabilities. This hormone, which secretion by the pineal gland is regulated by the circadian rhythm (light/dark cycle), is thought to help stabilize basic physiological parameters like body temperature and blood pressure. The expected favorable outcome of melatonin administration is associated however with the reported direct anti-oxidative, anti-apoptotic, and anti-inflammatory effects [106, 107]. The latter is thought to contribute to either the protection of myelin structure and/or promotion of its reconstruction, in spite of the lack of the influence on the reduction of cortical infarct volume resulting from brain injury, as deduced from the study on the rat model $[108,109]$. The encouraging data concerning the neuroprotective and immunomodulatory features of melatonin resulted in including this hormone in clinical trials as one of the potential therapeutic means to treat perinatal asphyxia.

Another example of a physiological molecule is erythropoietin (EPO, hematopoietin), a pleiotropic cytokine 
Table 1 Currently used treatments administrated to new born children who experienced perinatal asphyxia

\begin{tabular}{|c|c|c|}
\hline Biological factor & In vivo function & Natural source \\
\hline $\begin{array}{l}\text { Docosahexaenoic acid (DHA) - a long-chain } \\
\text { omega-3 fatty acid }\end{array}$ & $\begin{array}{l}\text { Sustains membrane fluidity and integrity; } \\
\text { contributes to the synaptic functioning; an } \\
\text { anti-inflammatory compound }\end{array}$ & $\begin{array}{l}\text { Maternal milk during breast-feeding period; sea } \\
\text { fish (like tuna, salmon, herring, sardines) } \\
\text { caviar, algae }\end{array}$ \\
\hline Resveratrol (3,5,4'-trihydroxy-trans-stilbene) & Enhances endogenous anti-oxidative defense & $\begin{array}{l}\text { Skin of grapes, blueberries, raspberries, red wine, } \\
\text { peanuts, dark chocolate }\end{array}$ \\
\hline Sodium butyrate & $\begin{array}{l}\text { Histone deacetylase inhibitor, regulates gene } \\
\text { expression through NF-kappaB cascade; reduces } \\
\text { expression of pro-inflammatory cytokines, } \\
\text { stimulates neurogenesis; protects } \\
\text { oligodendrocytes }\end{array}$ & $\begin{array}{l}\text { Produced from dietary fiber in the gut by } \\
\text { endogenous bacteria as the end-product of } \\
\text { intestinal microbial fermentation; milk fat } \\
\text { (so also in butter and cheese) }\end{array}$ \\
\hline Erythropoietin (EPO, hematopoietin) & $\begin{array}{l}\text { Indispensable for erythropoiesis, enhance } \\
\text { angiogenesis, exerts neuroregenerative, } \\
\text { anti-inflammatory and anti-apoptotic effects }\end{array}$ & $\begin{array}{l}\text { Hormone produced by interstitial fibroblasts in } \\
\text { the kidney }\end{array}$ \\
\hline Melatonin ( $N$-acetyl-5-methoxy tryptamine) & $\begin{array}{l}\text { Direct anti-oxidative, anti-apoptotic and } \\
\text { anti-inflammatory effects; protects myelin struc- } \\
\text { ture }\end{array}$ & $\begin{array}{l}\text { Hormone secreted predominantly by pineal } \\
\text { gland }\end{array}$ \\
\hline $\begin{array}{l}\text { Triiodothyronine (T3) and its prohormone, } \\
\text { thyroxine (T4) }\end{array}$ & $\begin{array}{l}\text { Engaged in physiological process of } \\
\text { oligodendrocyte maturation; promotes in vivo } \\
\text { remyelination }\end{array}$ & Hormones produced by the thyroid gland \\
\hline Mesenchymal stem cells (MSCs) & $\begin{array}{l}\text { Used for cell replacement, provide trophic support to } \\
\text { diseased tissue, exert anti-inflammatory and neu- } \\
\text { roprotective effect }\end{array}$ & $\begin{array}{l}\text { Bone marrow, umbilical cord (cord blood and } \\
\text { Wharton's jelly), adipose tissue, etc. }\end{array}$ \\
\hline
\end{tabular}

predominantly produced in kidneys and liver and responsible for erythropoiesis [110]. By binding to its specific membrane receptor EpoR, EPO promotes proliferation and differentiation of erythroid progenitor cell. Importantly, this cytokine expression is upregulated in response to hypoxia [111]. Moreover, EpoR is found on different cell types in brain [112]. EPO was shown to enhance angiogenesis after anoxic event [113-115] and was suggested to have neuroregenerative, anti-inflammatory, and anti-apoptotic effects in the brain [116, 117]. It turned out to be effective in reducing to some extend white matter damage after $\mathrm{HI}$ injury in neonatal rats and preterm fetal sheep and in improving behavioral outcomes $[118,119]$. Since nowadays EPO is routinely used in clinical practice to avoid or treat neonatal anemia [120], the additional advantages in preventing eventual neurological complications common in preterm neonates might supposedly be expected as well (phase 3 of clinical trials) [121-123].

According to the recently published data, magnesium sulfate was shown to accelerate the differentiation process of rat oligodendrocytes in vitro, although it did not ensure protection for mature cells against hypoxic-ischemic damage [124, 125]. While considering possible strategies aimed at rescuing oligodendrocyte progenitors from cell death and/or promoting their maturation, application of thyroid hormones should be taken into account. Triiodothyronine (T3) and its prohormone, thyroxine (T4), produced by the thyroid gland, are known to be engaged in physiological process of oligodendrocyte maturation and to promote remyelination in vivo [126, 127].
Another group of natural molecules comprising popular nutrients used to diminish fatal consequences of neurorodegenerative processes evoked during the hypoxicischemic episode could be distinguished. One of the potential remedies alleviating neurological deficits resulting from the asphyxic event is the docosahexaenoic acid (DHA), which is a long-chain omega-3 fatty acid (long-chain polyunsaturated fatty acids: LCPUFA) and yet the major polyunsaturated fatty acid in the adult mammalian brain. This phospholipid is responsible for membrane organization and integrity, exerts an impact on neurogenesis and neuroplasticity, contributes to modulating signal transduction pathways, participates in the myelination process, and affects the effectiveness of neurotransmission [128-131]. It has also been reported to possess anti-inflammatory properties and to participate in the development of the immune system in childhood [132-135]. Being crucial for a developing brain, DHA can be found in maternal milk during a lactation period (up to $1 \%$ of the total fatty acids) [136-138]. Supplementation with DHA was shown to be important for cognitive and visual development early in life and also useful for nervous system functioning during the life span [139-142]. Since LCPUFA, including DHA, can be easily found in seafood and certain plants [98, 143, 144], they have been recommended to be included in everyday, diversified diet. According to the very recent data, treatment with DHA turned out to be effective in the case of rat model of the neonatal hypoxia-ischemia. Accordingly, the beneficial effects of DHA administration seemed to result from both protecting neurons and myelin from destruction in inimical 
microenvironment and from reducing inflammatory response evoked by the $\mathrm{HI}$ episode. It was also shown to be effective in ameliorating cognitive deficits in rodent models $[145,146]$.

Resveratrol, a natural antioxidant found in grapes skin and red wine, is another example of neuroprotectant acting by enhancing endogenous anti-oxidative defense [147, 148]. Similar to the abovementioned molecules, it was shown to exert some beneficial effects on reducing cognitive impairments in the rodent model of stroke [149].

One of the worth mentioning molecules is also the sodium butyrate (SB), which is produced from dietary fiber in the gut by endogenous bacteria as the end-product of intestinal microbial fermentation. It acts as one of the histone deacetylase inhibitors (HDACs) and thus influences compaction of chromatin and regulates activation of genes engaged in progress of oligodendrocyte differentiation. HDACs may either initiate repression by modulating the acetylation state of nucleosomal histones/transcriptional regulators or directly bind to transcriptional regulators and function as transcriptional co-repressors [150]. SB has been also reported to possess immunomodulatory properties due to reducing the expression of proinflammatory cytokines [151-153]. In our recent studies on the rat model of neonatal hypoxia, the administration of SB was shown to exert neuroprotective, neurogenic, and antiinflammatory effect finally resulting in a significant reduction of brain damage [154]. This hope-rising observation concerned prevention of the HI-induced loss of neuroblasts and oligodendrocyte precursor cells, which is important for the initiation of the compensatory mechanism leading to amelioration of neurological deficiency.

Keeping in mind the diversified and detrimental effects of perinatal asphyxia, new treatments are intensely searched for and preclinically tested in context of their eventual adverse effects and the desired effectiveness in preventing neurodevelopmental disorders. Pharmacological interventions are difficult in vulnerable newborns, since they might interfere with the intense developmental processes. Among proposed new treatments, administration of the free radical scavengers and anti-oxidative compounds seem to confer beneficiary effects in terms of enhancing natural, endogenous anti-oxidative defense, which is inefficient in early human development [78]. Catalpol, an iridoid glycoside extracted from Rehmannia root, has been shown to protect pre-myelinating oligodendrocytes through ERK1/2 signaling pathway by suppressing $\mathrm{Ca}^{+}{ }^{+}$influx, reducing mitochondrial damage and inhibiting ROS overproduction [155]. Neuroprotective effects have been also achieved by administration of allopurinol (inhibitor of xanthine oxidase, the enzyme engaged in generation of superoxide particle), vitamin $E$ ( $\alpha$-tocopherol and $\beta$-tocopherol) with vitamin $\mathrm{C}$ (ascorbic acid) together counteracting lipid peroxidation, as well as deferoxamine, which is chelating agent for free iron (highly concentrated in oligodendrocytes) [156, 157]. Nonetheless, the new effective therapies preventing the harmful effects of oxidative stress and promoting reparative processes are needed to be developed and preclinically tested to provide safe and efficient treatment options for newborns.

\section{Cell Transplantation as a Neuroreparative Strategy}

A growing list of evidence from preclinical studies indicates that cell transplantation is an effective treatment option applied to prevent the symptoms of neurodegenerative processes which develop as a consequence of cell death or alteration in their differentiation and biological functions. Directly replenishing the nervous tissue with cells which are depleted in a result of the insult seems to be one of the main advantages of cell-based therapies. The mesenchymal stem cells obtained from various sources might be used either for direct engraftment with aim of their in vivo differentiation or for generation of neural progenitors. One of the most promising sources of mesenchymal stem cells is umbilical cord (cord blood and Wharton's jelly) $[158,159]$. In our very recent studies, human cord blood-derived cells were shown to be relatively easily differentiated into oligodendroglia-biased progenitors by application of the serum-free protocol based of using analogues of physiological molecules (PDGF-AA, T3, and extracellular matrix components like laminin and fibronectin) [160]. The obtained progenitors might in vivo give rise to oligodendrocyte with myelinating potential and/or to favorably act by modifying the local tissue microenvironment by secreting trophic factors and anti-inflammatory cytokines [89, 161].

Promoting neurological recovery via indirect bystander actions seems to be one of the main advantages of using cells with stem cell/progenitor characteristics $[162,163]$. Accordingly, transplantation of the mesenchymal stem cells was shown to contribute to the reduction of the lesion volume and protection of white matter and consequently to improve the motor function [164-166]. Thus, the cell-based therapies offer few advantages: a direct supplementation of the traumatized tissue with the exogenous cells, protection against further brain damage, promotion of the neuroregeneration, and improvement of the behavioral functions.

\section{Clinical Perspective}

When concluding on the therapeutic strategies for preventing leukodystrophic disorders resulting from perinatal asphyxia, it should be taken into consideration that neurons and glial cells are functionally interdependent. During development, oligodendrocyte maturation and myelinogenesis is guided by the external stimuli, including signals provided by differentiating neurons [167-169]. While some of them regulate the differentiation process (PDGF-A, neuregulin: NGR, etc.), others play a role in matching oligodendrocytes to 
the axonal surface (cell adhesion molecule L1, the polysialylated neuronal cell adhesion molecule: PSANCAM; Jagged 1). Similarly, neuron survival and proficient functioning strongly depends on oligodendrocytes and compact myelin sheath [170-173]. Keeping the above in mind, both the compounds protecting either neurons or oligodendrocytes, as well as those preserving the myelin structure, might turn out to be effective in preventing white matter damage and subsequent neurodevelopmental disorders. On the one hand, the common feature of the enumerated compounds is their relative fine tolerance by very young organisms, as deduced from very rare reports on side effects evoked by natural molecules administration. On the other hand, however, their efficacy of improving the overall well-being of human neonates, who experienced perinatal hypoxia, is still very limited. It results from a wide range of the injuries evoked by HI, the course of pregnancy (like potential chronic hypoxia, hemorrhages), the procedures initiated in response to the insult and time of their implementation, very limited number of clinical trials, and confined abilities of the already existing compounds to cure severe trauma. The solution for increasing the efficiency of successful treatment would be to foster preclinical studies on animal models with new substances leading to detailed description of mechanisms of their action and their eventual side effects on both molecular and systemic levels. The other one could be combining the already known treatments with the aim of increasing their beneficial effects, like for instance administration of neuroprotectants (sodium butyrate, melatonin, DHA) with cell therapies promoting endogenous repair. As deduced from the available data concerning the outcomes of the applied therapies (which turned out to be ineffective in some cases), in spite there is a growing list of the treatments available, the clinical protocol should be every time chosen individually for the given case of perinatal asphyxia event.

Acknowledgements This study was financially supported by NCN (National Science Centre, Poland) grant no. 2014/15/B/NZ4/01875. Authors express their gratitude to Professor Malgorzata FrontczakBaniewicz, who performed detailed ultrastructural studies at Electron Microscopy Platform (Mossakowski Medical Research Centre, Polish Academy of Sciences).

\section{Compliance with Ethical Standards}

Conflict of Interest The authors declare that they have no conflict of interest.

Open Access This article is distributed under the terms of the Creative Commons Attribution 4.0 International License (http:// creativecommons.org/licenses/by/4.0/), which permits unrestricted use, distribution, and reproduction in any medium, provided you give appropriate credit to the original author(s) and the source, provide a link to the Creative Commons license, and indicate if changes were made.

\section{References}

1. van Handel M, Swaab H, de Vries LS, Jongmans MJ (2007) Longterm cognitive and behavioral consequences of neonatal encephalopathy following perinatal asphyxia: a review. Eur J Pediatr 166(7):645-654

2. Bryce J, Boschi-Pinto C, Shibuya K, Black RE (2005) WHO estimates of the causes of death in children. Lancet 365(9465): $1147-1152$

3. Ment LR, Hirtz D, Hüppi PS (2009) Imaging biomarkers of outcome in the developing preterm brain. Lancet Neurol 8(11):10421055. doi:10.1016/S1474-4422(09)70257-1

4. Liu L, Oza S, Hogan D, Perin J, Rudan I, Lawn JE, Cousens S, Mathers C et al (2015) Global, regional, and national causes of child mortality in $2000-13$, with projections to inform post2015 priorities: an updated systematic analysis. Lancet 385(9966):430-440

5. Lee AC, Cousens S, Wall SN, Niermeyer S, Darmstadt GL, Carlo WA, Keenan WJ, Bhutta ZA et al (2001) Neonatal resuscitation and immediate newborn assessment and stimulation for the prevention of neonatal deaths: a systematic review, meta-analysis and Delphi estimation of mortality effect. BMC Public Health Suppl 3: S12. doi:10.1186/1471-2458-11-S3-S12

6. Pammi M, Dempsey EM, Ryan CA, Barrington KJ (2016) Newborn resuscitation training programmes reduce early neonatal mortality. Neonatology 110:210-224

7. Te Pas AB, Sobotka K, Hooper SB (2016) Novel approaches to neonatal resuscitation and the impact on birth asphyxia. Clin Perinatol 43(3):455-467

8. de Haan M, Wyatt JS, Roth S, Vargha-Khadem F, Gadian D, Mishkin M (2006) Brain and cognitive-behavioural development after asphyxia at term birth. Dev Sci 9(4):350-358

9. Aarnoudse-Moens CS, Weisglas-Kuperus N, van Goudoever JB, Oosterlaan J (2009) Meta-analysis of neurobehavioral outcomes in very preterm and/or very low birth weight children. Pediatrics 124(2):717-728

10. Marret S, Marchand-Martin L, Picaud JC, Hascoët JM, Arnaud C, Rozé JC, Truffert P, Larroque B et al (2013) EPIPAGE study group brain injury in very preterm children and neurosensory and cognitive disabilities during childhood: the EPIPAGE cohort study. PLoS One 8(5):e62683. doi:10. 1371/journal.pone.0062683

11. Clayton BL, Huang A, Dukala D, Soliven B, Popko B (2017) Neonatal hypoxia results in peripheral nerve abnormalities. Am J Pathol

12. Budday S, Steinmann P, Kuhl E (2015) Physical biology of human brain development. Front Cell Neurosci 9:257. doi:10.3389/fncel. 2015.00257 eCollection 2015

13. Lim S, Kaiser M (2015) Developmental time windows for axon growth influence neuronal network topology. Biol Cybern 109(2): 275-286

14. Jiang X, Nardelli J (2016) Cellular and molecular introduction to brain development. Neurobiol Dis 92(Pt A):3-17

15. Schoenemann PT, Sheehan MJ, Glotzer LD (2005) Prefrontal white matter volume is disproportionately larger in humans than in other primates. Nat Neurosci 8(2):242-252

16. Herculano-Houzel S (2014) The glia/neuron ratio: how it varies uniformly across brain structures and species and what that means for brain physiology and evolution. Glia 62(9):1377-1391. doi: 10.1002/glia.22683

17. von Bartheld CS, Bahney J, Herculano-Houzel S (2016) The search for true numbers of neurons and glial cells in the human brain: a review of 150 years of cell counting. J Comp Neurol 524(18):3865-3895. doi:10.1002/cne.24040 
18. Bakhti M, Aggarwal S, Simons M (2014) Myelin architecture: zippering membranes tightly together. Cell Mol Life Sci 71(7): 1265-1277. doi:10.1007/s00018-013-1492-0

19. Mobius W, Nave KA, Werner HB (2016) Electron microscopy of myelin: structure preservation by high-pressure freezing. Brain Res. doi:10.1016/j.brainres.2016.02.027

20. Baumann N, Pham-Dinh D (2001) Biology of oligodendrocyte and myelin in the mammalian central nervous system. Physiol Rev 81(2):871-927

21. Dean JM, Moravec MD, Grafe M, Abend N, Ren J, Gong X et al (2011) Strain-specific differences in perinatal rodent oligodendrocyte lineage progression and its correlation with human. Dev Neurosci 33(3-4):251-260

22. Barateiro A, Fernandes A (2014) Temporal oligodendrocyte lineage progression: in vitro models of proliferation, differentiation and myelination. Biochim Biophys Acta 1843(9):1917-1929

23. Farrer RG, Quarles RH (1999) GT3 and its O-acetylated derivative are the principal A2B5-reactive gangliosides in cultured O2A lineage cells and are down-regulated along with O-acetyl GD3 during differentiation to oligodendrocytes. J Neurosci Res 57(3): 371-380

24. Dawson MR, Levine JM, Reynolds R (2000) NG2-expressing cells in the central nervous system: are they oligodendroglial progenitors? J Neurosci Res 61(5):471-479

25. Binamé F, Sakry D, Dimou L, Jolivel V, Trotter J (2013) NG2 regulates directional migration of oligodendrocyte precursor cells via Rho GTPases and polarity complex proteins. J Neurosci 33(26):10858-10874

26. Hughes EG, Kang SH, Fukaya M, Bergles DE (2013) Oligodendrocyte progenitors balance growth with self-repulsion to achieve homeostasis in the adult brain. Nat Neurosci 16(6): 668-676

27. Tekki-Kessaris N, Woodruff R, Hall AC, Gaffield W, Kimura S, Stiles CD, Rowitch DH, Richardson WD (2001) Hedgehogdependent oligodendrocyte lineage specification in the telencephalon. Development 128:2545-2554

28. Kuhlmann T, Miron V, Cui Q, Wegner C, Antel J, Brück W (2008) Differentiation block of oligodendroglial progenitor cells as a cause for remyelination failure in chronic multiple sclerosis. Brain 131(Pt 7):1749-1758

29. Islam MS, Tatsumi K, Okuda H, Shiosaka S, Wanaka A (2009) Olig2-expressing progenitor cells preferentially differentiate into oligodendrocytes in cuprizone-induced demyelinated lesions. Neurochem Int 54(3-4):192-198

30. Niu J, Mei F, Wang L, Liu S, Tian Y, Mo W, Li H, Lu QR et al (2012) Phosphorylated olig1 localizes to the cytosol of oligodendrocytes and promotes membrane expansion and maturation. Glia 60(9):1427-1436. doi:10.1002/glia.22364

31. Dai J, Bercury KK, Jin W, Macklin WB (2015) Olig1 acetylation and nuclear export mediate oligodendrocyte development. J Neurosci 35(48):15875-15893

32. Nishiyama A (2007) Polydendrocytes: NG2 cells with many roles in development and repair of the CNS. Neuroscientist 13(1):62-76

33. Hermann A, Brandt MD, Loewenbrück KF, Storch A (2010) "Silenced" polydendrocytes: a new cell type within the oligodendrocyte progenitor cell population? Cell Tissue Res 340(1):45-50

34. Levine JM, Reynolds R, Fawcett JW (2001) The oligodendrocyte precursor cell in health and disease. Trends Neurosci 24(1):39-47

35. Dawson MR, Polito A, Levine JM, Reynolds R (2003) NG2expressing glial progenitor cells: an abundant and widespread population of cycling cells in the adult rat CNS. Mol Cell Neurosci 24(2):476-488

36. Geha S, Pallud J, Junier MP, Devaux B, Leonard N, Chassoux F, Chneiweiss H, Daumas-Duport C et al (2010) NG2+/Olig2+ cells are the major cycle-related cell population of the adult human normal brain. Brain Pathol 20(2):399-411
37. Simon C, Götz M, Dimou L (2011) Progenitors in the adult cerebral cortex: cell cycle properties and regulation by physiological stimuli and injury. Glia 59(6):869-881

38. Sommer I, Schachner M (1981) Monoclonal antibodies (O1 to O4) to oligodendrocyte cell surfaces: an immunocytological study in the central nervous system. Dev Biol 83(2):311-327

39. Bansal R, Warrington AE, Gard A, Ranscht B, Pfeiffer S (1989) Multiple and novel specificities of monoclonal antibodies O1, O4, and R-mAb used in the analysis of oligodendrocyte development. J Neurosci Res 24:548-557

40. Reynolds R, Hardy R (1997) Oligodendroglial progenitors labeled with the $\mathrm{O} 4$ antibody persist in the adult rat cerebral cortex in vivo. J Neurosci Res 47:455-470

41. Back SA, Luo NL, Borenstein NS, Levine JM, Volpe JJ, Kinney HC (2001) Late oligodendrocyte progenitors coincide with the developmental window of vulnerability for human perinatal white matter injury. J Neurosci 21(4):1302-1312

42. Brunner C, Lassmann H, Waehneldt TV, Matthieu JM, Linington C (1989) Differential ultrastructural localization of myelin basic protein, myelin/oligodendroglial glycoprotein, and 2', 3'-cyclic nucleotide $3^{\prime}$-phosphodiesterase in the CNS of adult rats. J Neurochem 52:296-304

43. Sprinkle TJ (1989) 3'-cyclic nucleotide 3'-phosphodiesterase, an oligodendrocyte-Schwann cell and myelin-associated enzyme of the nervous system. Crit Rev Neurobiol 4(3):235-301

44. Pfeiffer SE, Warrington AE, Bansal R (1993) The oligodendrocyte and its many cellular processes. Trends Cell Biol 3:191-197

45. McAlarney T, Ogino M, Apostolski S, Latov N (1995) Specificity and cross-reactivity of anti-galactocerebroside antibodies. Immunol Investig 24(4):595-606

46. Snaidero N, Velte C, Myllykoski M, Raasakka A, Ignatev A, Werner HB, Erwig MS, Mobius W et al (2017) Antagonistic functions of MBP and CNP establish cytosolic channels in CNS myelin. Cell Rep 18(2):314-323

47. Salzer JL, Holmes WP, Colman DR (1987) The amino acid sequences of the myelin-associated glycoproteins: homology to the superimmunoglobulin gene superfamily. J Cell Biol 104:957-965

48. Popot JL, Pham-Dinh D, Dautigny A (1991) Major myelin proteolipid: the 4-alpha-helix topology. J Membr Biol 120:233246.12

49. Weimbs T, Stoffel W (1994) Topology of CNS myelin proteolipid protein: evidence for the nonenzymatic glycosylation of extracytoplasmic domains in normal and diabetic animals. Biochemistry 33:10408-10415

50. Han H, Myllykoski M, Ruskamo S, Wang C, Kursula P (2013) Myelin-specific proteins: a structurally diverse group of membrane-interacting molecules. Biofactors 39(3):233-241

51. Inouye H, Kirschner DA (2015) Evolution of myelin ultrastructure and the major structural myelin proteins. Brain Res. doi:10.1016/j. brainres.2015. 10.037

52. Vassall KA, Bamm VV, Harauz G (2015) MyelStones: the executive roles of myelin basic protein in myelin assembly and destabilization in multiple sclerosis. Biochem J 472(1):17-32

53. Yuen TJ, Silbereis JC, Griveau A, Chang SM, Daneman R, Fancy SP, Zahed H, Maltepe E et al (2014) Oligodendrocyte-encoded HIF function couples postnatal myelination and white matter angiogenesis. Cell 58(2):383-396. doi:10.1016/j.cell.2014.04.052

54. Skoff RP, Bessert DA, Barks JD, Song D, Cerghet M, Silverstein FS (2001) Hypoxic-ischemic injury results in acute disruption of myelin gene expression and death of oligodendroglial precursors in neonatal mice. Int J Dev Neurosci 19(2):197-208

55. Rothstein RP, Levison SW (2005) Gray matter oligodendrocyte progenitors and neurons die caspase-3 mediated deaths subsequent to mild perinatal hypoxic/ischemic insults. Dev Neurosci 27(2-4):149-159 
56. Segovia KN, McClure M, Moravec M, Luo NL, Wan Y, Gong X, Riddle A, Craig A et al (2008) Arrested oligodendrocyte lineage maturation in chronic perinatal white matter injury. Ann Neurol 63(4):520-530

57. Buser JR, Maire J, Riddle A, Gong X, Nguyen T, Nelson K, Luo NL, Ren J et al (2012) Arrested preoligodendrocyte maturation contributes to myelination failure in premature infants. Ann Neurol 71(1):93-109

58. Zaidi AU, Bessert DA, Ong JE, Xu H, Barks JD, Silverstein FS, Skoff RP (2004) New oligodendrocytes are generated after neonatal hypoxic-ischemic brain injury in rodents. Glia 46(4): 380-390

59. Omari KM, John GR, Sealfon SC, Raine CS (2005) CXC chemokine receptors on human oligodendrocytes: implications for multiple sclerosis. Brain 128(Pt 5):1003-1015

60. Morell P, Quarles R (1995) Myelin formation, structure and biochemistry. In: Basic neurochemistry, Molecular, cellular and medical aspects, 6th edn. Lippincott-Raven, Philadelphia 1999. ISBN10: 0-397-51820-X

61. Schmitt S, Castelvetri LC, Simons M (2015) Metabolism and functions of lipids in myelin. Biochim Biophys Acta 1851(8): 999-1005

62. Susuki K (2010) Myelin: a specialized membrane for cell communication. Nat Educ 3(9):59

63. Miron VE, Kuhlmann T, Antel JP (2011) Cells of the oligodendroglial lineage, myelination, and remyelination. Biochim Biophys Acta 1812(2):184-193

64. Arai K, Lo EH (2009) An oligovascular niche: cerebral endothelial cells promote the survival and proliferation of oligodendrocyte precursor cells. J Neurosci 29(14):4351-4355

65. Pham L-DD, Hayakawa K, Seo JH, Nguyen M-N, Som AT, Lee BJ et al (2012) Crosstalk between oligodendrocytes and cerebral endothelium contributes to vascular remodeling after white matter injury. Glia 60:875-881

66. Maki T, Maeda M, Uemura M, Lo EK, Terasaki Y, Liang AC, Shindo A, Choi YK et al (2015) Potential interactions between pericytes and oligodendrocyte precursor cells in perivascular regions of cerebral white matter. Neurosci Lett 15(597):164-169

67. Jiang L, Shen F, Degos V, Schonemann M, Pleasure SJ, Mellon SH, Young WL, Su H (2011) Oligogenesis and oligodendrocyte progenitor maturation vary in different brain regions and partially correlate with local angiogenesis after ischemic stroke. Transl Stroke Res 2(3):366-375

68. Koutsakis C, Kazanis I (2016) How necessary is the vasculature in the life of neural stem and progenitor cells? Evidence from evolution, development and the adult nervous system. Front Cell Neurosci 10:35. doi:10.3389/fncel.2016.00035 eCollection 2016

69. Seo JH, Maki T, Maeda M, Miyamoto N, Liang AC, Hayakawa K, Pham LD, Suwa F et al (2014) Oligodendrocyte precursor cells support blood-brain barrier integrity via TGF- $\beta$ signaling. PLoS One 9(7):e103174

70. Delcour M, Russier M, Amin M, Baud O, Paban V, Barbe MF, Coq JO (2012) Impact of prenatal ischemia on behavior, cognitive abilities and neuroanatomy in adult rats with white matter damage. Behav Brain Res 232(1):233-244

71. Martinez-Biarge M, Bregant T, Wusthoff CJ, Chew AT, DiezSebastian J, Rutherford MA, Cowan FM (2012) White matter and cortical injury in hypoxic-ischemic encephalopathy: antecedent factors and 2-year outcome. J Pediatr 61(5):799-807. doi:10. 1016/j.jpeds. 2012.04.054

72. Baud O, Li J, Zhang Y, Neve RL, Volpe JJ (2004) Rosenberg PA nitric oxide-induced cell death in developing oligodendrocytes is associated with mitochondrial dysfunction and apoptosis-inducing factor translocation. Eur J Neurosci 20(7):1713-1726
73. Martinvalet D, Zhu P, Lieberman J (2005) Granzyme A induces caspase-independent mitochondrial damage, a required first step for apoptosis. Immunity 22(3):355-370

74. di Penta A, Moreno B, Reix S, Fernandez-Diez B, Villanueva M, Errea O, Escala N, Vandenbroeck K et al (2013) Oxidative stress and proinflammatory cytokines contribute to demyelination and axonal damage in a cerebellar culture model of neuroinflammation. PLoS One 8(2):e54722

75. Jana M, Pahan K (2005) Redox regulation of cytokine-mediated inhibition of myelin gene expression in human primary oligodendrocytes. Free Radic Biol Med 39:823-831

76. French HM, Reid M, Mamontov P, Simmons RA, Grinspan JB (2009) Oxidative stress disrupts oligodendrocyte maturation. J Neurosci Res 87(14):3076-3087

77. Baud O, Haynes R, Wang H, Folkerth RD, Li J, Volpe J, Rosenberg PA (2004) Developmental up-regulation of MnSOD in rat oligodendrocytes confers protection against oxidative injury. Eur J Neurosci 19:2669-2681

78. Folkerth R, Haynes R, Borenstein NS, Volpe JJ, Kinney HC (2004) Developmental lag in superoxide dismutases relative to other antioxidant enzymes in premyelinated human telencephalic white matter. J Neuropathol Exp Neurol 63:990-999

79. VanRollins M, Woltjer RL, Yin H, Morrow JD, Montine TJ (2008) F2-dihomo-isoprostanes arise from free radical attack on adrenic acid. J Lipid Res 49(5):995-1005

80. Tonni G, Leoncini S, Signorini C, Ciccoli L, De Felice C (2014) Pathology of perinatal brain damage: background and oxidative stress markers. Arch Gynecol Obstet 290(1):13-20

81. Milne GL, Yin H, Hardy KD, Davies SS, Roberts LJ 2nd (2011) Isoprostane generation and function. Chem Rev 11(10):5973-5996

82. Longini M, Belvisi E, Proietti F, Bazzini F, Buonocore G, Perrone S (2017) Oxidative stress biomarkers: establishment of reference values for isoprostanes, AOPP, and NPBI in cord blood. Mediat Inflamm 2017:1758432

83. Garcia-Flores LA, Medina S, Martínez-Hernández P, Oger C, Galano JM, Durand T, Casas-Pina T, Ferreres F et al (2017) Snapshot situation of oxidative degradation of the nervous system, kidney, and adrenal glands biomarkers-neuroprostane and dihomo-isoprostanes-urinary biomarkers from infancy to elderly adults. Redox Biol 11:586-591

84. Back SA, Luo NL, Mallinson RA, O’Malley JP, Wallen LD, Frei B, Morrow JD, Petito CK et al (2005) Selective vulnerability of preterm white matter to oxidative damage defined by F2isoprostanes. Ann Neurol 58:108-120

85. Simons M, Trajkovic K (2006) Neuron-glia communication in the control of oligodendrocyte function and myelin biogenesis. J Cell Biochem 119:4381-4389

86. Morrison BM, Lee Y, Rothstein JD (2013) Oligodendroglia: metabolic supporters of axons. Trends Cell Biol 23(12):644-651

87. Saab AS, Tzvetanova ID, Nave KA (2013) The role of myelin and oligodendrocytes in axonal energy metabolism. Curr Opin Neurobiol 23(6):1065-1072

88. Baltan S (2015) Can lactate serve as an energy substrate for axons in good times and in bad, in sickness and in health? Metab Brain Dis 30(1):25-30

89. Sypecka J, Sarnowska A (2014) The neuroprotective effect exerted by oligodendroglial progenitors on ischemically impaired hippocampal cells. Mol Neurobiol 49(2):685-701

90. Bizzarro MJ, Li FY, Katz K, Shabanova V, Ehrenkranz RA, Bhandari V (2014) Temporal quantification of oxygen saturation ranges: an effort to reduce hyperoxia in the neonatal intensive care unit. J Perinatol 34(1):33-38

91. Sola A, Golombek SG, Montes Bueno MT, Lemus-Varela L, Zuluaga C, Domínguez F, Baquero H, Young Sarmiento AE et al (2014) Safe oxygen saturation targeting and monitoring in 
preterm infants: can we avoid hypoxia and hyperoxia? Acta Paediatr 103(10):1009-1018

92. Vali P, Mathew B, Lakshminrusimha S (2015) Neonatal resuscitation: evolving strategies. Matern Health Neonatol Perinatol 1

93. Wyllie J, Bruinenberg J, Roehr CC, Rüdiger M, Trevisanuto D, Urlesberger B (2015) European Resuscitation Council Guidelines for Resuscitation 2015: Section 7. Resuscitation and support of transition of babies at birth. Resuscitation 95:249-263

94. Perlman JM (2006) Intervention strategies for neonatal hypoxicischemic cerebral injury. Clin Ther 28(9):1353-1365

95. Verklan MT (2009) The chilling details: hypoxic-ischemic encephalopathy. J Perinat Neonatal Nurs 23(1):59-68

96. Cooper DJ (2011) Induced hypothermia for neonatal hypoxicischemic encephalopathy: pathophysiology, current treatment, and nursing considerations. Neonatal Netw 30(1):29-35

97. Silveira RC, Procianoy RS (2015) Hypothermia therapy for newborns with hypoxic ischemic encephalopathy. J Pediatr 91(6 Suppl 1):S78-S83. doi:10.1016/j.jped.2015.07.004

98. Doughman SD, Krupanidhi S, Sanjeevi CB (2007) Omega-3 fatty acids for nutrition and medicine: considering microalgae oil as a vegetarian source of EPA and DHA. Curr Diabetes Rev 3(3):198-203

99. Azzopardi D, Strohm B, Marlow N, Brocklehurst P, Deierl A, Eddama O, Goodwin J, Halliday HL et al (2014) TOBY study group. Effects of hypothermia for perinatal asphyxia on childhood outcomes. N Engl J Med 371(2):140-149. doi:10.1056/ NEJMoa1315788

100. Xiong M, Li J, Ma SM, Yang Y, Zhou WH (2013) Effects of hypothermia on oligodendrocyte precursor cell proliferation, differentiation and maturation following hypoxia ischemia in vivo and in vitro. Exp Neurol 247:720-729. doi:10.1016/j.expneurol. 2013.03.015

101. Ichinose M, Kamei Y, Iriyama T, Imada S, Seyama T, Toshimitsu M, Asou H, Yamamoto M et al (2014) Hypothermia attenuates apoptosis and protects contact between myelin basic proteinexpressing oligodendroglial-lineage cells and neurons against hypoxia-ischemia. J Neurosci Res 92(10):1270-1285

102. Wang B, Armstrong JS, Reyes M, Kulikowicz E, Lee JH, Spicer D, Bhalala U, Yang ZJ et al (2016) White matter apoptosis is increased by delayed hypothermia and rewarming in a neonatal piglet model of hypoxic ischemic encephalopathy. Neuroscience 316:296-310. doi:10.1016/j.neuroscience.2015.12.046

103. Robertson NJ, Faulkner S, Fleiss B, Bainbridge A, Andorka C, Price D, Powell E, Lecky-Thompson L et al (2013) Melatonin augments hypothermic neuroprotection in a perinatal asphyxia model. Brain 136(Pt 1):90-105

104. Broad KD, Fierens I, Fleiss B, Rocha-Ferreira E, Ezzati M, Hassell J, Alonso-Alconada D, Bainbridge A et al (2016) Inhaled $45-50 \%$ argon augments hypothermic brain protection in a piglet model of perinatal asphyxia. Neurobiol Dis 87:29-38

105. Dai HB, Xu MM, Lv J, Ji XJ, Zhu SH, Ma RM, Miao XL, Duan ML (2016) Mild hypothermia combined with hydrogen sulfide treatment during resuscitation reduces hippocampal neuron apoptosis via NR2A, NR2B, and PI3K-Akt signaling in a rat model of cerebral ischemia-reperfusion injury. Mol Neurobiol 53(7):4865-4873

106. Biran V, Phan Duy A, Decobert F, Bednarek N, Alberti C, Baud O (2014) Is melatonin ready to be used in preterm infants as a neuroprotectant? Dev Med Child Neurol 56(8):717-723. doi:10. 1111/dmcn. 12415

107. Joshi N, Biswas J, Nath C, Singh S (2015) Promising role of melatonin as neuroprotectant in neurodegenerative pathology. Mol Neurobiol 52(1):330-340. doi:10.1007/s12035-014-8865-8

108. Villapol S, Fau S, Renolleau S, Biran V, Charriaut-Marlangue C, Baud O (2011) Melatonin promotes myelination by decreasing white matter inflammation after neonatal stroke. Pediatr Res 69(1):51-55

109. Alonso-Alconada D, Alvarez A, Lacalle J, Hilario E (2012) Histological study of the protective effect of melatonin on neural cells after neonatal hypoxia-ischemia. Histol Histopathol 27(6): 771-783

110. Jelkmann W (2011) Regulation of erythropoietin production. J Physiol 589(Pt 6):1251-1258

111. Stockmann C, Fandrey J (2006) Hypoxia-induced erythropoietin production: a paradigm for oxygen-regulated gene expression. Clin Exp Pharmacol Physiol 33(10):968-979

112. Ott C, Martens H, Hassouna I, Oliveira B, Erck C, Zafeiriou MP, Peteri UK, Hesse D et al (2015) Widespread expression of erythropoietin receptor in brain and its induction by injury. Mol Med. doi:10.2119/molmed.2015.00192

113. Wang L, Zhang Z, Wang Y, Zhang R, Chopp M (2004) Treatment of stroke with erythropoietin enhances neurogenesis and angiogenesis and improves neurological function in rats. Stroke 35: $1732-1737$

114. Iwai M, Cao G, Yin W, Stetler RA, Liu J, Chen J (2007) Erythropoietin promotes neuronal replacement through revascularization and neurogenesis after neonatal hypoxia/ischemia in rats. Stroke 38:2795-2803

115. Yan F, Zhang M, Meng Y, Li H, Yu L, Fu X, Tang Y, Jiang C (2016) Erythropoietin improves hypoxic-ischemic encephalopathy in neonatal rats after short-term anoxia by enhancing angiogenesis. Brain Res 1651:104-113. doi:10.1016/j.brainres.2016. 09.024

116. Gonzalez FF, Abel R, Almli CR, Mu D, Wendland M, Ferriero DM (2009) Erythropoietin sustains cognitive function and brain volume after neonatal stroke. Dev Neurosci 31:403-411. doi:10. $1159 / 000232558$

117. Fan X, van Bel F, van der Kooij MA, Heijnen CJ, Groenendaal F (2013) Hypothermia and erythropoietin for neuroprotection after neonatal brain damage. Pediatr Res 73:18-23

118. Larpthaveesarp A, Georgevits M, Ferriero DM, Gonzalez FF (2016) Delayed erythropoietin therapy improves histological and behavioral outcomes after transient neonatal stroke. Neurobiol Dis 3:57-63. doi:10.1016/j.nbd.2016.04.006

119. Ren Q, Zhang XF, Yang JY (2016) Erythropoietin reduces white matter damage in two-day-old rats exposed to hypoxic/ischemia injury. Neurol Res 8:1-7

120. Aher SM, Ohlsson A (2014) Late erythropoietin for preventing red blood cell transfusion in preterm and/or low birth weight infants. Cochrane Database Syst Rev 23(4):CD004868. doi:10.1002/ 14651858.CD004868.pub4

121. Wu YW, Bauer LA, Ballard RA, Ferriero DM, Glidden DV, Mayock DE, Chang T, Durand DJ et al (2012) Erythropoietin for neuroprotection in neonatal encephalopathy: safety and pharmacokinetics. Pediatrics 130(4):683-691. doi:10.1542/peds. 2012-0498

122. Juul SE, Mayock DE, Comstock BA, Heagerty PJ (2015) Neuroprotective potential of erythropoietin in neonates; design of a randomized trial. Matern Health Neonatol Perinatol 1:27. doi:10.1186/s40748-015-0028-z

123. Hoeber D, Sifringer M, van de Looij Y, Herz J, Sizonenko SV, Kempe K, Serdar M, Palasz J et al (2016) Erythropoietin restores long-term neurocognitive function involving mechanisms of neuronal plasticity in a model of hyperoxia-induced preterm brain injury. Oxidative Med Cell Longev 2016:9247493. doi:10.1155/ 2016/9247493

124. Anabrees J (2013) Magnesium sulphate for newborns with HIE; synopsis of evidence from a systematic review. J Clin Neonatol 2(3):114-116. doi:10.4103/2249-4847.119989

125. Itoh K, Maki T, Shindo A, Egawa N, Liang AC, Itoh N, Lo EH, Lok J et al (2016) Magnesium sulfate protects oligodendrocyte 
lineage cells in a rat cell-culture model of hypoxic-ischemic injury. Neurosci Res 106:66-69. doi:10.1016/j.neures.2015.12.004

126. Fernández M, Baldassarro VA, Sivilia S, Giardino L, Calzà L (2016) Inflammation severely alters thyroid hormone signaling in the central nervous system during experimental allergic encephalomyelitis in rat: direct impact on OPCs differentiation failure. Glia 64(9):1573-1589. doi:10.1002/glia.23025

127. Lee JY, Petratos S (2016) Thyroid hormone signaling in oligodendrocytes: from extracellular transport to intracellular signal. Mol Neurobiol 53(9):6568-6583

128. Salem N Jr, Litman B, Kim HY, Gawrisch K (2001) Mechanisms of action of docosahexaenoic acid in the nervous system. Lipids 36:945-959

129. Guesnet P, Alessandri JM (2011) Docosahexaenoic acid (DHA) and the developing central nervous system (CNS) - implications for dietary recommendations. Biochimie 93(1):7-12

130. Crupi R, Marino A, Cuzzocrea S (2013) n-3 fatty acids: role in neurogenesis and neuroplasticity. Curr Med Chem 20(24): 2953-63.1

131. Weiser MJ, Butt CM, Mohajeri MH (2016) Docosahexaenoic acid and cognition throughout the lifespan. Nutrients 8(2):99

132. Si TL, Liu Q, Ren YF, Li H, Xu XY, Li EH, Pan SY, Zhang JL et al (2016) Enhanced anti-inflammatory effects of DHA and quercetin in lipopolysaccharide-induced RAW264.7 macrophages by inhibiting NF-KB and MAPK activation. Mol Med Rep 14(1): 499-508

133. Orr SK, Palumbo S, Bosetti F, Mount HT, Kang JX, Greenwood CE, Ma DW, Serhan CN et al (2013) Unesterified docosahexaenoic acid is protective in neuroinflammation. $\mathrm{J}$ Neurochem 127(3):378-393

134. Heras-Sandoval D, Pedraza-Chaverri J, Pérez-Rojas JM (2016) Role of docosahexaenoic acid in the modulation of glial cells in Alzheimer's disease. J Neuroinflammation 13(1):61

135. Richard C, Lewis ED, Field CJ (2016) Evidence for the essentiality of arachidonic and docosahexaenoic acid in the postnatal maternal and infant diet for the development of the infant's immune system early in life. Appl Physiol Nutr Metab 41(5):461-475

136. Gibson RA, Makrides M (2001) Long-chain polyunsaturated fatty acids in breast milk: are they essential? Adv Exp Med Biol 501: 375-383

137. Brenna JT, Varamini B, Jensen RG, Diersen-Schade DA, Boettcher JA, Arterburn LM (2007) Docosahexaenoic and arachidonic acid concentrations in human breast milk worldwide. Am J Clin Nutr 85(6):1457-1464

138. Moukarze S, Dyer RA, Keller BO, Elango R, Innis SM (2016) Human milk plasmalogens are highly enriched in long-chain PUFAs. J Nutr

139. Auestad N, Scott DT, Janowsky JS, Jacobsen C, Carroll RE, Montalto MB, Halter R, Qiu W et al (2003) Visual, cognitive, and language assessments at 39 months: a follow-up study of children fed formulas containing long-chain polyunsaturated fatty acids to 1 year of age. Pediatrics 112(3 Pt 1):e177-e183

140. Cederholm T, Salem N Jr, Palmblad J (2013) $\omega$-3 fatty acids in the prevention of cognitive decline in humans. Adv Nutr 4(6): 672-676

141. Gould JF, Smithers LG, Makrides M (2013) The effect of maternal omega-3 (n-3) LCPUFA supplementation during pregnancy on early childhood cognitive and visual development: a systematic review and meta-analysis of randomized controlled trials. Am J Clin Nutr 97(3):531-544

142. Joffre C, Nadjar A, Lebbadi M, Calon F, Laye S (2014) n-3 LCPUFA improves cognition: the young, the old and the sick. Prostaglandins Leukot Essent Fat Acids 91(1-2):1-20

143. Howe PR, Downing JA, Grenyer BF, Grigonis-Deane EM, Bryden WL (2002) Tuna fishmeal as a source of DHA for n-3
PUFA enrichment of pork, chicken, and eggs. Lipids 37(11): 1067-1076

144. Baker EJ, Miles EA, Burdge GC, Yaqoob P, Calder PC (2016) Metabolism and functional effects of plant-derived omega-3 fatty acids in humans. Prog Lipid Res 64:30-56

145. Zhao Y, Calon F, Julien C, Winkler JW, Petasis NA, Lukiw WJ, Bazan NG (2011) Docosahexaenoic acid-derived neuroprotectin $\mathrm{D} 1$ induces neuronal survival via secretase- and PPAR $\gamma$-mediated mechanisms in Alzheimer's disease models. PLoS One 6(1): e15816

146. Arteaga O, Revuelta M, Urigüen L, Martínez-Millán L, Hilario E, Álvarez A (2016) Docosahexaenoic acid reduces cerebral damage and ameliorates long-term cognitive impairments caused by neonatal hypoxia-ischemia in rats. Mol Neurobiol 2016

147. Singh N, Agrawal M, Doré S (2013) Neuroprotective properties and mechanisms of resveratrol in in vitro and in vivo experimental cerebral stroke models. ACS Chem Neurosci 4(8):1151-1162

148. Lopez MS, Dempsey RJ, Vemuganti R (2015) Resveratrol neuroprotection in stroke and traumatic CNS injury. Neurochem Int 89: 75-82. doi:10.1016/j.neuint.2015.08.009

149. Arteaga O, Revuelta M, Urigüen L, Álvarez A, Montalvo H, Hilario E (2015) Pretreatment with resveratrol prevents neuronal injury and cognitive deficits induced by perinatal hypoxiaischemia in rats. PLoS One 10(11):e0142424

150. Yu Y, Casaccia P, Lu QR (2010) Shaping the oligodendrocyte identity by epigenetic control. Epigenetics 5(2):124-128

151. Kim HJ, Rowe M, Ren M, Hong JS, Chen PS, Chuang DM (2007) Histone deacetylase inhibitors exhibit anti-inflammatory and neuroprotective effects in a rat permanent ischemic model of stroke: multiple mechanisms of action. J Pharmacol Exp Ther 321(3): 892-901

152. Patnala R, Arumugam TV, Gupta N, Dheen ST (2016) HDAC inhibitor sodium butyrate-mediated epigenetic regulation enhances neuroprotective function of microglia during ischemic stroke. Mol Neurobiol 2016. doi:10.1007/s12035-016-0149-Z

153. Xu J, Chen X, Yu S, Su Y, Zhu W (2016) Effects of early intervention with sodium butyrate on gut microbiota and the expression of inflammatory cytokines in neonatal piglets. PLoS One 11(9):e0162461. doi:10.1371/journal.pone.0162461

154. Ziemka-Nalecz M, Jaworska J, Sypecka J, Polowy R, Filipkowski RK, Zalewska T (2016) Sodium butyrate, a histone deacetylase inhibitor, exhibits neuroprotective/neurogenic effects in a rat model of neonatal hypoxia-ischemia. Mol Neurobiol. doi:10.1007/ s12035-016-0049-2

155. Cai Q, Ma T, Li C, Tian Y, Li H (2016) Catalpol protects premyelinating oligodendrocytes against ischemia-induced oxidative injury through ERK1/2 signaling pathway. Int J Biol Sci 12(12): 1415-1426

156 Papazisis G, Pourzitaki C, Sardeli C, Lallas A, Amaniti E, Kouvelas D (2008) Deferoxamine decreases the excitatory amino acid levels and improves the histological outcome in the hippocampus of neonatal rats after hypoxia-ischemia. Pharmacol Res 57(1):73-78

157 Tataranno ML, Perrone S, Longini M, Buonocore G. (2015) New antioxidant drugs for neonatal brain injury. Oxid Med Cell Longev 2015:108251.

158 Cotten CM, Murtha AP, Goldberg RN, Grotegut CA, Smith PB, Goldstein RF, Fisher KA, Gustafson KE et al (2014) Feasibility of autologous cord blood cells for infants with hypoxic-ischemic encephalopathy. J Pediatr 164(5):973-979.e1. doi:10.1016/j.jpeds. 2013.11.036

159 Sypecka J, Sarnowska A (2015) Mesenchymal cells of umbilical cord and umbilical cord blood as a source of human oligodendrocyte progenitors. Life Sci 139:24-29. doi:10.1016/j.lfs. 2015.08.006 
160 Sypecka J, Ziemka-Nalecz M, Dragun-Szymczak P, Zalewska T (2017) A simple, xeno-free method for oligodendrocyte generation from human neural stem cells derived from umbilical cord: engagement of gelatinases in cell commitment and differentiation. J Tissue Eng Regen Med 11(5):1442-1455

161 Ubhi K, Rockenstein E, Mante M, Inglis C, Adame A, Patrick C et al (2010) Neurodegeneration in a transgenic mouse model of multiple system atrophy is associated with altered expression of oligodendroglial-derived neurotrophic factors. J Neurosci 30(18): 6236-6246

162 Donega V, van Velthoven CT, Nijboer CH, Kavelaars A, Heijnen CJ (2013) The endogenous regenerative capacity of the damaged newborn brain: boosting neurogenesis with mesenchymal stem cell treatment. J Cereb Blood Flow Metab 33(5):625-634

163 Doeppner TR, Hermann DM (2014) Stem cell-based treatments against stroke: observations from human proof-of-concept studies and considerations regarding clinical applicability. Front Cell Neurosci 8:357. doi:10.3389/fncel.2014.00357

164 Bae SH, Kong TH, Lee HS, Kim KS, Hong KS, Chopp M, Kang MS, Moon J (2012) Long-lasting paracrine effects of human cord blood cells on damaged neocortex in an animal model of cerebral palsy. Cell Transplant 21(11):2497-2515

165 Zhu LH, Bai X, Zhang N, Wang SY, Li W, Jiang L (2014) Improvement of human umbilical cord mesenchymal stem cell transplantation on glial cell and behavioral function in a neonatal model of periventricular white matter damage. Brain Res 1563:1321. doi:10.1016/j.brainres.2014.03.030

166 van Velthoven CT, Dzietko M, Wendland MF, Derugin N, Faustino J, Heijnen CJ, Ferriero DM, Vexler ZS (2016) Mesenchymal stem cells attenuate MRI-identifiable injury, protect white matter, and improve long-term functional outcomes after neonatal focal stroke in rats. J Neurosci Res. doi:10.1002/jnr.23954

167 Trajkovic K, Dhaunchak AS, Goncalves JT, Wenzel D, Schneider A, Bunt G, Nave KA, Simons M (2006) Neuron to glia signaling triggers myelin membrane exocytosis from endosomal storage sites. J Cell Biol 172(6):937-948

168 Piaton G, Gould RM, Lubetzki C (2010) Axon-oligodendrocyte interactions during developmental myelination, demyelination and repair. J Neurochem 114(5):1243-1260

169 Bhatt A, Fan LW, Pang Y (2014) Strategies for myelin regeneration: lessons learned from development. Neural Regen Res 9(14): 1347-1350. doi:10.4103/1673-5374.137586

170 Ghosh A, Manrique-Hoyos N, Voigt A, Schulz J, Kreutzfeldt M, Merkler D, Simons M (2011) Targeted ablation of oligodendrocytes triggers axonal damage. PLoS One 6(7)

171 Oluich LJ, Stratton JA, Xing YL, Ng SW, Cate HS, Sah P, Windels F, Kilpatrick TJ et al (2012) Targeted ablation of oligodendrocytes induces axonal pathology independent of overt demyelination. J Neurosci 32(24):8317-8330

172 de Hoz L, Simons M (2015) The emerging functions of oligodendrocytes in regulating neuronal network behaviour. BioEssays 37(1):60-69. doi:10.1002/bies.201400127

173 Makarewicz D, Słomka M, Danysz W, Łazarewicz JW (2015) Effects of mGluR5 positive and negative allosteric modulators on brain damage evoked by hypoxia-ischemia in neonatal rats. Folia Neuropathol 53(4):301-308 